


\title{
SCREENING APPROACHES FOR METHANE MITIGATING POTENTIAL OF TANNIN-CONTAINING PLANTS UNDER IN VITRO RUMEN ENVIRONMENT
}

\author{
A. Jayanegara, M. Ridla and Nahrowi \\ Department of Nutrition and Feed Technology, Faculty of Animal Science, \\ Bogor Agricultural University, Jl. Agatis Kampus IPB Dramaga Bogor 16680 - Indonesia \\ Corresponding E-mail: anuragaja@ipb.ac.id
}

Received July 17, 2012; Accepted September 06, 2012

\begin{abstract}
ABSTRAK
Tujuan penelitian ini adalah untuk melakukan pemilahan terhadap hijauan mengandung tanin yang memiliki sifat menurunkan emisi gas metana dengan menggunakan pendekatan univariabel, bivariabel dan multivariabel (principal component analysis, PCA). Sampel hijauan berasal dari beberapa negara, yakni Indonesia ( $n=27$ spesies), Mongolia $(n=14)$, Swiss $(n=16)$ dan Jerman $(n=3)$. Hijauan diinkubasi secara in vitro dengan cairan rumen-buffer pada suhu $39^{\circ} \mathrm{C}$ selama 24 jam. Total produksi gas diamati sebagai indikator kualitas hijauan dan emisi gas metana diukur. Hasil menunjukkan bahwa, berdasarkan pendekatan bivariabel, hijauan yang menghasilkan emisi metana rendah umumnya juga memiliki kualitas yang kurang baik atau rendah total produksi gasnya, kecuali Rhus typhina yakni sebesar $43 \mathrm{ml}$ metana/200 mg bahan kering. Loading plot dari PCA menunjukkan bahwa semua fraksi fenolik hijauan berlawanan arah dengan gas metana dan total produksi gas. Hijauan yang berlawanan arah dengan produksi metana adalah Bergenia crassifolia, Swietenia mahagoni, Clidemia hirta, Peltiphyllum peltatum, Acacia villosa dan $R$. typhina. Dapat disimpulkan bahwa, untuk hijauan mengandung tanin, pemilahan berdasarkan pendekatan univariabel, bivariabel dan multivariabel terkait emisi gas metana menunjukkan hasil yang serupa.
\end{abstract}

Kata kunci : Metana, kualitas hijauan, pemilahan, korelasi, tanin, fenolik

\begin{abstract}
The aim of the present study was to conduct univariate, bivariate and multivariate (principal component analysis, PCA) approaches in the screening of tannin-containing plants from various collection sites for their $\mathrm{CH}_{4}$ mitigating properties. Plant samples were obtained from various collection sites in different countries, i.e. Indonesia $(n=27$ species), Mongolia $(n=14)$, Switzerland $(n=16)$ and Germany $(n=3)$. The plants were incubated in vitro with buffered-rumen fluid at $39^{\circ} \mathrm{C}$ for $24 \mathrm{~h}$. Total gas production was recorded as an indicator of feed quality and emission of $\mathrm{CH}_{4}$ was measured. Results showed that, based on bivariate screening, generally, plants possessed low $\mathrm{CH}_{4}$ production had low quality or low total gas production except Rhus typhina, i.e. $43 \mathrm{ml} / 200 \mathrm{mg}$ DM. The loading plot of PCA showed that all phenolic fractions were in the opposite direction with $\mathrm{CH}_{4}$ and total gas production. Plants clustered together in reverse direction to that of $\mathrm{CH}_{4}$ were Bergenia crassifolia root and leaf, Swietenia mahagoni, Clidemia hirta, Peltiphyllum peltatum, Acacia villosa and R. typhina. It was conluded that, for tannin-containing plants, screenings based on univariate, bivariate and multivariate approaches in relation to ruminal $\mathrm{CH}_{4}$ emission led to similar results
\end{abstract}

Keywords : Methane, forage quality, screening, correlation, tannin, phenolic

\section{INTRODUCTION}

Forage quality is a determining factor for the productivity of ruminants. Several important properties related to forage quality are energy content, fiber, protein, anti-nutritional compounds and the digestibility of forage in the digestive tract. On the other hand, the concern on global warming due to accumulation of green-house gases has increased in the last decades, including 
methane $\left(\mathrm{CH}_{4}\right)$. Ruminants are among major contributors of atmospheric $\mathrm{CH}_{4}$ which is generated from microbial fermentation in the rumen (Moss et al., 2000), and may be more prevalent in the tropical area. It has been estimated that ruminants produce 80 million tons of $\mathrm{CH}_{4}$ annually which accounts for $28 \%$ of total anthropogenic $\mathrm{CH}_{4}$ emissions (Beauchemin et al., 2008). Such emission is not only associated with environmental problem but also reflects the loss of energy from animal and, hence, may reduce the amount of energy for production purposes. Up to $12 \%$ of the gross energy from feed consumed by ruminants is lost as $\mathrm{CH}_{4}$ (McCrabb and Hunter, 1999).

The above-mentioned factors have led to the exploration of forages that are not only good in quality but also are able to reduce $\mathrm{CH}_{4}$ formation in the rumen. Tannin-containing forages or extracts have been reported to be able to reduce $\mathrm{CH}_{4}$ emission from ruminants, both in in vitro and in vivo experiments (e.g., Tavendale et al., 2005; Tiemann et al., 2008; Bhatta et al., 2009). However, further research still needs to be conducted to find most promising tannincontaining plants, i.e. effective in mitigating $\mathrm{CH}_{4}$ emission at simultaneously of high quality. Screenings of plants that possess $\mathrm{CH}_{4}$ mitigating properties have been done using different approaches, such as using univariate approach (Soliva et al., 2008), bivariate (Bodas et al., 2008; Garcia-Gonzalez et al., 2008) and multivariate (Jayanegara et al., 2011a). However, no studies so far have attempted to address these different approaches simultaneously when screening the plants and to compare the results obtained.

Based on this background, therefore, the aim of the present study is to conduct univariate, bivariate and multivariate approaches in the screening of tannin-containing plants from various collection sites for their $\mathrm{CH}_{4}$ mitigating properties. A main point of interest is to observe whether these different approaches will lead to a different conclusion when screening the plants. Additionally, as a second objective, this study is aimed at observing the relationships between plant phenolic fractions and $\mathrm{CH}_{4}$ emission using an extended database of plants collected from various sites, i.e. Indonesia, Mongolia, Switzerland and Germany.

\section{MATERIALS AND METHODS}

\section{Plant Samples}

Plant samples were obtained from various collection sites in different countries, i.e. Indonesia $(n=27$ species), Mongolia $(n=14)$, Switzerland $(n=16)$ and Germany $(n=3)$. The data were based on some previous studies, i.e. Jayanegara et al. (2009a) for the plants from Mongolia and Germany, Jayanegara et al. (2011a) for the plants from Indonesia, and Jayanegara et al. (2011b) for the plants from Switzerland. Plant samples from Indonesia consisted of one grass, four herbs, nine shrubs and 13 tree species; all of them are either commonly used as ruminant feeds in rural areas or as traditional veterinary medicinal plants. The plants collected from Mongolia are used locally in the region of production as medicinal plants. Plants from Switzerland were obtained from the region of the Alps at altitudes of 800-2300 m above sea level, consisted of two grasses, eight non-leguminous herbs, three herbaceous legumes and three tree species. The majority of these plants is used for grazing of ruminants during European summer period, particularly for dairy production. The plants from Germany were collected from the Botanical Garden of the University of Hohenheim in Stuttgart. All plant samples were oven dried at $50-60^{\circ} \mathrm{C}$ and ground to pass $1 \mathrm{~mm}$ sieve. Each plant was encoded by its country of origin, i.e. I, $\mathrm{M}, \mathrm{S}$ and $\mathrm{G}$ for plants obtained from Indonesia, Mongolia, Switzerland and Germany, respectively, and numbered according to alphabetical order within country.

\section{Chemical Composition and In Vitro Procedures}

The plant samples were analyzed for their chemical composition. These included crude protein (CP), ether extract (EE; AOAC, 1997), neutral detergent fiber (NDF), acid detergent fiber (ADF; Van Soest et al., 1991), total phenols (TP), non-tannin phenols (NTP), total tannins (TT), condensed tannins (CT; Makkar, 2003a) and hydrolysable tannins (HT; Singh et al., 2005). The plants were incubated in vitro with bufferedrumen fluid by using the Hohenheim gas test method (Menke and Steingass, 1988), incubated at $39^{\circ} \mathrm{C}$ for $24 \mathrm{~h}$. In addition, standard hay and concentrate (obtained from the Institute of Animal Nutrition, University of Hohenheim, Stuttgart, Germany) were incubated, serving as control for the successful incubation. After the incubation, 
total gas production was recorded as an indicator of feed quality. Emission of $\mathrm{CH}_{4}$ was measured by using an infrared methane analyzer (Goel et al., 2008) or a gas chromatograph (Soliva and Hess, 2007). These two different methods result in a similar $\mathrm{CH}_{4}$ value of hay standard, i.e. between 160-170 ml/1 gas.

\section{Statistical Analysis}

Data of all plants from various collection sites were tabulated into a database. Minimum and maximum values for each variable were recorded, and mean and standard deviation were calculated. Pearson's correlation analysis was performed to the data, i.e. the chemical composition and fermentation variables (total gas production and $\mathrm{CH}_{4}$ emission). Screening approaches were based on univariate $\left(\mathrm{CH}_{4}\right.$ only), bivariate (total gas and $\mathrm{CH}_{4}$ ) and multivariate (all variables investigated) using the principal component analysis (PCA). For the univariate approach, the plants considered were those which produced $\mathrm{CH}_{4} \leq$ average $\mathrm{CH}_{4}$ across all plants minus $1 \times$ standard deviation. For the bivariate approach, the screening was based on a twodimensional plot between total gas and $\mathrm{CH}_{4}$. For the multivariate approach, a PCA was applied to the data with Kaiser's criterion, i.e. Eigenvalue $\geq$ 1.0 to extract the principal components (PC) without rotation method. This procedure generated factor loading and factor score. The first two PC were plotted both for the loading and the score. The loading plot is used for describing the relationship among variables and the score plot is used for classifying the plants according to the loading. All statistical analyses were conducted using SPSS version 17.0 (2008) and the figures were generated using SigmaPlot version 11.0 (2008).

\section{RESULTS}

\section{Chemical Composition}

Summary of chemical composition of the plants investigated is presented in Table 1. Plant samples collected from Indonesia contained the highest $\mathrm{CP}$ contents (on average basis) compared to from other collection sites. Very high $\mathrm{CP}$ contents were found in the leaves of Carica papaya (386 g/kg DM; code I7) and Manihot esculenta (377 g/kg DM; I17) across all plants. All plants contained low EE with the average less than $35 \mathrm{~g} / \mathrm{kg}$ DM from the four collection sites. Plants from Mongolia contained higher ADF than the others. Quite a diverse TP contents were found across all collection sites, except those from Switzerland. The average of TP in these plants was $31 \mathrm{~g} / \mathrm{kg} \mathrm{DM}$ with the highest was found in Hedysarum hedysaroides, i.e. $69 \mathrm{~g} / \mathrm{kg} \mathrm{DM} \mathrm{(S8).}$ This pattern was similarly observed for TT, CT and HT. Several plants, i.e. Rhus typhina (G2), Acacia villosa (I2) and Clidemia hirta (I8) contained TT more than $200 \mathrm{~g} / \mathrm{kg}$ DM. Very high CT contents were found in Vaccinium vitis idea (M14) and Swietenia mahagoni (I27) with the values of 175 and $86 \mathrm{~g} / \mathrm{kg} \mathrm{DM}$, respectively.

\section{Relationships between Variables}

Variables CP and EE were unrelated to total gas production and $\mathrm{CH}_{4}$ (Table 2). Both NDF and ADF were positively correlated (both at $\mathrm{P}<0.001$ ) with $\mathrm{CH}_{4}$ emission, however, only ADF was negatively correlated with total gas $(\mathrm{P}<0.05)$. All phenolic fractions were negatively correlated with $\mathrm{CH}_{4}$ by following the order of magnitude: TP > TT > HT > NTP > CT. The phenolics were also negatively correlated with total gas production.

\section{Screening of Plants}

Across all plants, the average $\mathrm{CH}_{4}$ emission after $24 \mathrm{~h}$ in vitro incubation was $137( \pm 32) \mathrm{ml} / 1$ gas (Table 1). Therefore, for the screening based on univariate approach, the promising plants were those which produced $\mathrm{CH}_{4} \leq 105 \mathrm{ml} / 1$ gas. These plants were (ordered from lowest to highest $\mathrm{CH}_{4}$ ) Bergenia crassifolia root (M4), Peltiphyllum peltatum (G1), S. mahagoni (I27), A. villosa (I2), Eugenia aquea (I11), Myristica fragrans (I21), B. crassifolia leaf (M3), Pithecellobium jiringa (I24), R. typhina (G2) and C. hirta (I8). Screening based on bivariate approach is presented in Figure 1. It appeared that, generally, plants possessed low $\mathrm{CH}_{4}$ production had low quality, i.e. below the average of total gas production. Among plants that produced low $\mathrm{CH}_{4}$, only $R$. typhina $(\mathrm{G} 2)$ resulted in a high total gas production, i.e. $43 \mathrm{ml} / 200 \mathrm{mg}$ DM. Salsola laricifolia (M8), Hibiscus tiliaceus (I12) and Canna indica (I6) had simultaneously high $\mathrm{CH}_{4}$ emission and low total gas.

In relation to screening plants based on the multivariate approach, loading and score plots generated from PCA are shown in Figure 2. The PC1 and PC2 explained $42.3 \%$ and $23.3 \%$ of the 
Table 1: Summary of Chemical Composition of Plants from Various Collection Sites and Ruminal Fermentation Variables in vitro

\begin{tabular}{|c|c|c|c|c|c|c|c|c|c|c|c|}
\hline \multirow[t]{2}{*}{ Item } & $\mathrm{CP}$ & $\mathrm{EE}$ & NDF & ADF & $\begin{array}{c}\text { TP } \\
(\mathrm{g} / \mathrm{kg}\end{array}$ & $\begin{array}{l}\text { NTP } \\
\text { matte }\end{array}$ & $\begin{array}{c}\text { TT } \\
\ldots \ldots .\end{array}$ & $\begin{array}{l}\text { CT } \\
\ldots \ldots . .\end{array}$ & $\begin{array}{l}\text { HT } \\
\ldots \ldots \ldots \ldots . . . . .\end{array}$ & $\begin{array}{l}\text { Gas } \\
(\mathrm{ml})\end{array}$ & $\begin{array}{l}\mathrm{CH}_{4} \\
(\mathrm{ml} / \mathrm{l})\end{array}$ \\
\hline & \multicolumn{11}{|c|}{ Indonesia $(\mathrm{n}=27$ species) } \\
\hline Minimum & 79 & 11 & 155 & 135 & 14 & 4 & 2 & 0 & 2 & 5.3 & 68 \\
\hline Maximum & 386 & 65 & 710 & 476 & 236 & 102 & 220 & 86 & 206 & 42.8 & 185 \\
\hline Mean & 215 & 30 & 371 & 281 & 90 & 26 & 65 & 21 & 44 & 23.4 & 127 \\
\hline SD & 90 & 14 & 137 & 100 & 71 & 24 & 66 & 23 & 59 & 10.7 & 29 \\
\hline \multicolumn{12}{|c|}{ Mongolia ( $\mathrm{n}=14$ species) } \\
\hline Minimum & 33 & 6 & 226 & 169 & 20 & 9 & 4 & 0 & 0 & 11.5 & 44 \\
\hline Maximum & 246 & 35 & 626 & 509 & 320 & 144 & 178 & 175 & 164 & 44.8 & 220 \\
\hline Mean & 114 & 21 & 444 & 352 & 94 & 43 & 51 & 20 & 33 & 27.5 & 153 \\
\hline SD & 52 & 10 & 136 & 107 & 109 & 47 & 64 & 46 & 51 & 9.7 & 43 \\
\hline \multicolumn{12}{|c|}{ Switzerland ( $\mathrm{n}=16$ species) } \\
\hline Minimum & 91 & 6 & 218 & 157 & 8 & 8 & 0 & 0 & 0 & 29.5 & 129 \\
\hline Maximum & 247 & 35 & 753 & 344 & 69 & 35 & 38 & 21 & 34 & 49.9 & 176 \\
\hline Mean & 156 & 19 & 379 & 263 & 31 & 20 & 12 & 3 & 9 & 40.6 & 148 \\
\hline SD & 47 & 8 & 128 & 52 & 15 & 7 & 12 & 6 & 8 & 5.8 & 12 \\
\hline \multicolumn{12}{|c|}{ Germany ( $\mathrm{n}=3$ species $)$} \\
\hline Minimum & 113 & 17 & 191 & 174 & 57 & 13 & 36 & 1 & 21 & 22.2 & 57 \\
\hline Maximum & 169 & 56 & 322 & 185 & 222 & 53 & 209 & 16 & 208 & 49.3 & 125 \\
\hline Mean & 141 & 31 & 244 & 181 & 160 & 29 & 131 & 11 & 120 & 38.2 & 95 \\
\hline SD & 28 & 22 & 69 & 6 & 90 & 21 & 88 & 8 & 94 & 14.2 & 35 \\
\hline \multicolumn{12}{|c|}{ Overall ( $\mathrm{n}=60$ species) } \\
\hline Minimum & 33 & 6 & 155 & 135 & 8 & 4 & 0 & 0 & 0 & 5.3 & 44 \\
\hline Maximum & 386 & 65 & 753 & 509 & 320 & 144 & 220 & 175 & 208 & 49.9 & 220 \\
\hline Mean & 172 & 25 & 384 & 288 & 79 & 28 & 51 & 15 & 36 & 30.0 & 137 \\
\hline SD & 81 & 13 & 136 & 97 & 79 & 29 & 63 & 28 & 55 & 11.9 & 32 \\
\hline
\end{tabular}

$\mathrm{ADF}$, acid detergent fiber; $\mathrm{CP}$, crude protein; CT, condensed tannins; EE, ether extract; HT, hydrolysable tannins; NDF, neutral detergent fiber; NTP, non-tannin phenols; SD, standard deviation; TP, total phenols; TT, total tannins

total variation, respectively. It is clear that all phenolic fractions were in the opposite direction with $\mathrm{CH}_{4}$ and total gas production (Figure 2a). However, less clear relationships were observed between the other chemical constituents $(\mathrm{CP}, \mathrm{EE}$, $\mathrm{NDF}$ and $\mathrm{ADF}$ ) and the in vitro fermentation variables. Some plants were clustered together in reverse direction to that of $\mathrm{CH}_{4}$ (Figure 2b). These plants were B. crassifolia root (M4), B. crassifolia leaf (M3), S. mahagoni (I27), C. hirta (I8), P. peltatum (G1), A. villosa (I2) and $R$. typhina (G2). Variable $\mathrm{CH}_{4}$ and total gas production appeared to be in close direction in the loading plot of PCA.

\section{DISCUSSION}

\section{Plant Phenolics and $\mathrm{CH}_{4}$ Emission}

Negative relationships between all phenolic fractions and $\mathrm{CH}_{4}$ emission suggest the role of plant phenolics on mitigating the respective green-house gas under anaerobic condition in the 
Table 2. Correlations between Chemical Composition of Plants and Total Gas Production and $\mathrm{CH}_{4}$ Emission $(\mathrm{n}=60)$

\begin{tabular}{lll}
\hline Variable & Gas & $\mathrm{CH}_{4}$ \\
\hline CP & 0.08 & 0.05 \\
EE & -0.01 & -0.18 \\
NDF & -0.23 & $0.49 * * *$ \\
ADF & $-0.27 *$ & $0.45^{* * *}$ \\
TP & $-0.53^{* * *}$ & $-0.77 * * *$ \\
NTP & $-0.35 * *$ & $-0.52^{* * *}$ \\
TT & $-0.51 * * *$ & $-0.73^{* * *}$ \\
CT & $-0.46^{* * *}$ & $-0.33^{*}$ \\
HT & $-0.36 * *$ & $-0.67 * * *$ \\
\hline
\end{tabular}

$\mathrm{ADF}$, acid detergent fiber; $\mathrm{CP}$, crude protein; $\mathrm{CT}$, condensed tannins; EE, ether extract; HT, hydrolysable tannins; NDF, neutral detergent fiber; NTP, non-tannin phenols; TP, total phenols; TT, total tannins

$* \mathrm{P}<0.05 ; * * \mathrm{P}<0.01 ; * * * \mathrm{P}<0.001$ rumen, and this confirms some studies that had been reported previously (Tiemann et al., 2008; Bhatta et al., 2009). Phenolics, particularly tannins reduce $\mathrm{CH}_{4}$ emission through several ways, i.e. through reduction in fiber digestion which decreases $\mathrm{H}_{2}$ production, inhibition of the growth of methanogens (Tavendale et al., 2005), and reduction of protozoa population where part of the methanogens are associated symbiotically on the surface or inside the micro-fauna (Vogels et al., 1980). Within the tannin classes, based on the correlation data, both CT and HT contributed to lower $\mathrm{CH}_{4}$ emission as also shown by Bhatta et al. (2009). It is hypothesized that lower $\mathrm{CH}_{4}$ due to $\mathrm{CT}$ is more through reduction in fiber digestion as compared to the HT, confirmed by much stronger negative correlation of the former with the total gas production. This might be related to the fact that CT is resistant from microbial degradation in the rumen due to its aromatic structure, while HT is degradable due to the presence of carbohydrate in its structure (McSweeney et al., 2001; Makkar, 2003b). Interestingly, the NTP plays also a role in lowering $\mathrm{CH}_{4}$ with less adverse effect on the total gas production. This is in accordance to our

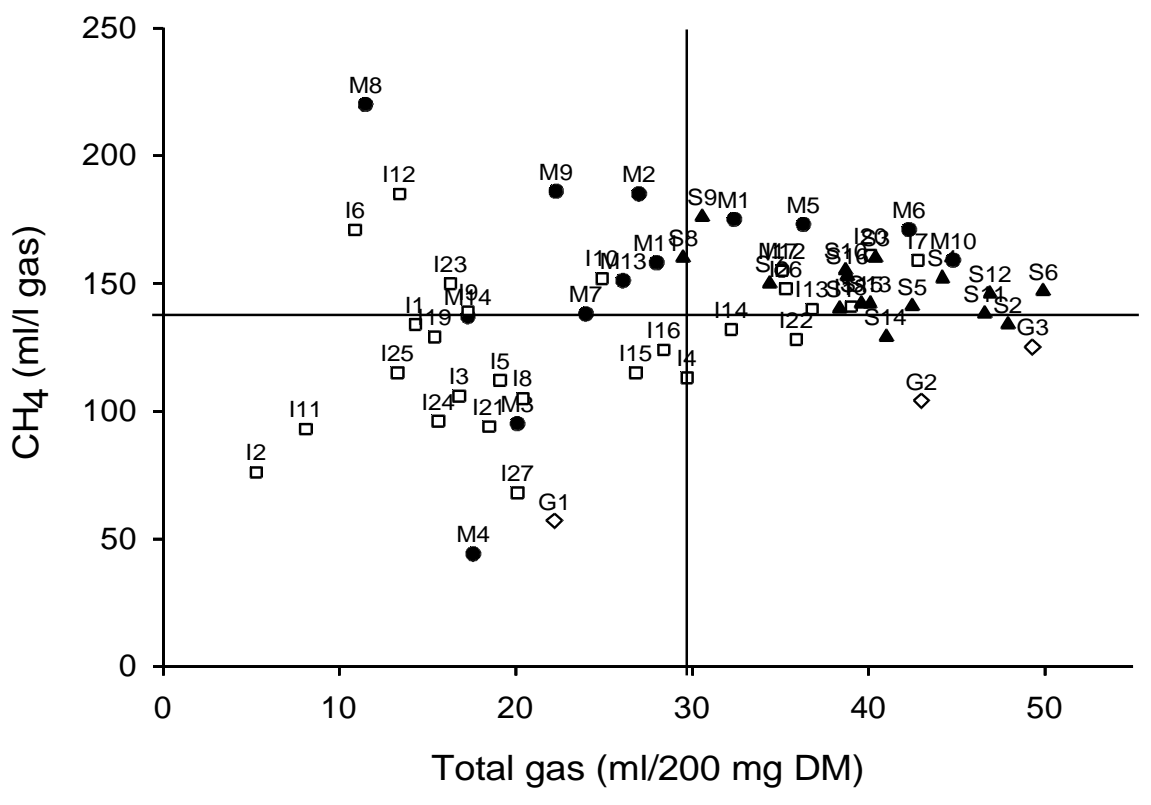

Figure 1: Bivariate approach for screening plants based on total gas produced and $\mathrm{CH}_{4}$ emission. Vertical and horizontal lines show the average of total gas and $\mathrm{CH}_{4}$ across all plants, respectively. I, plant samples from Indonesia ( $\square)$; M, plant samples from Mongolia $(\bullet)$; S, plant samples from Switzerland ( $\mathbf{\Delta})$; $\mathrm{G}$, plant samples from Germany $(\diamond)$ 


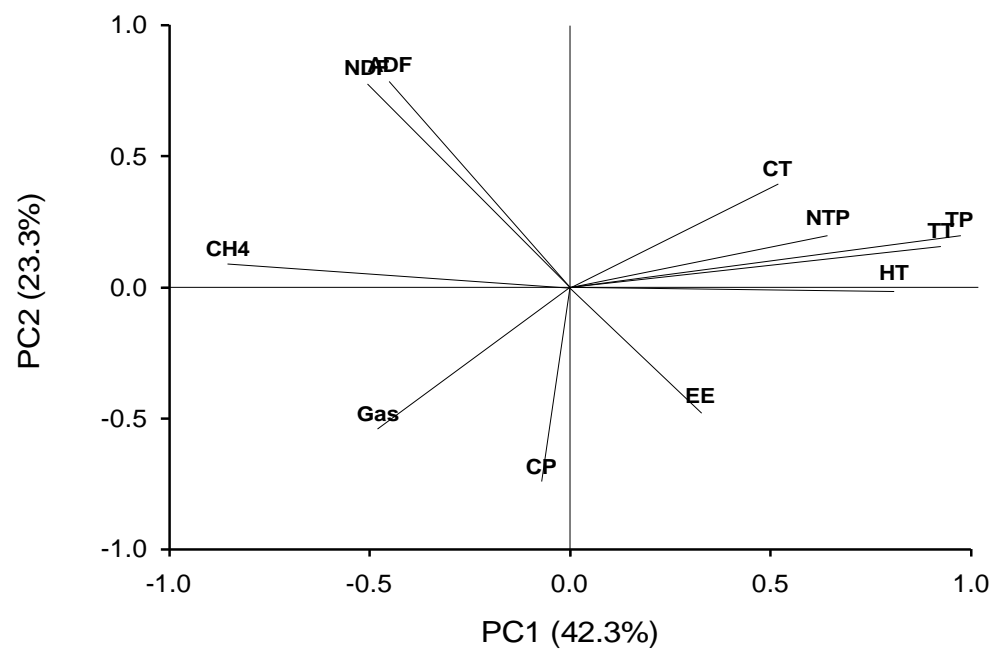

(a)

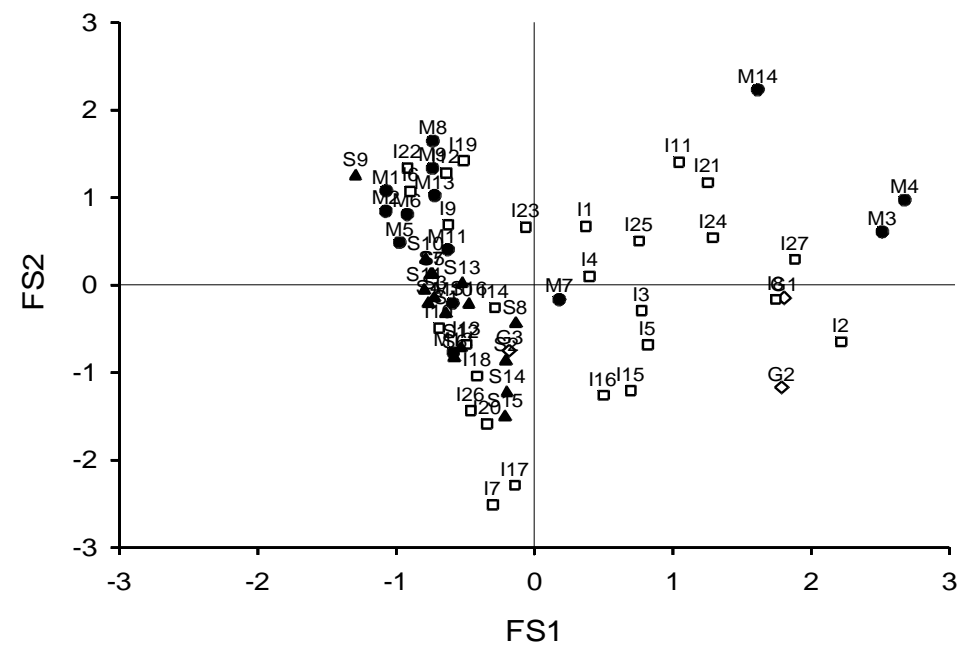

(b)

Figure 2. Loading Plot (a) and Score Plot (b) from Principal Component Analysis as a Multivariate Approach for Screening Plants. ADF, acid detergent fiber; CP, crude protein; CT, condensed tannins; EE, ether extract; FS, factor score; HT, hydrolysable tannins; NDF, neutral detergent fiber; NTP, non-tannin phenols; PC, principal component; TP, total phenols; TT, total tannins; I, plant samples from Indonesia ( $\square$ ); M, plant samples from Mongolia $(\bullet)$; S, plant samples from Switzerland $(\boldsymbol{\Delta})$; G, plant samples from Germany $(\diamond)$

previous study that the addition of some simple phenolic acids, namely caffeic, p-coumaric, ferulic and cinnamic acids on hay diets at $5 \mathrm{mM}$ concentration decreased in vitro $\mathrm{CH}_{4}$ emission without impairing the organic matter digestibility (Jayanegara et al., 2009b).

\section{Different Screening Approaches}

Screenings based on univariate, bivariate and multivariate approaches led to similar results to certain extent; the promising plants (low $\mathrm{CH}_{4}$ production) obtained from univariate approach were also presence when screened by bivariate and multivariate approaches. However, the 
screening by univariate approach is not as selective as the others. One may obtain plants with low $\mathrm{CH}_{4}$ production potential, but without considering the other important aspect, i.e. the forage quality. Among the promising plants obtained by the univariate screening, for instance, A. villosa (I2) and E. aquea (I11) resulted in poor quality performance as shown by the very low total gas production $(\leq 10 \mathrm{ml} / 200 \mathrm{mg} \mathrm{DM}$ incubated) of both plants. The bivariate approach may overcome this problem by considering the forage quality related variable (Bodas et al., 2008). Although almost all plants possessed low $\mathrm{CH}_{4}$ emission had low quality, still, a good quality plant could be obtained, i.e. $R$. typhina (G2). What is clear from this approach is to avoid the utilization of plants that possessed high $\mathrm{CH}_{4}$ emission and low total gas production such as Salsola laricifolia (M8), Canna indica (I6) and Hibiscus tiliaceous (I12).

The loading plot of PCA showed the relationships between variables in a twodimensional plot. Variables that are in the same direction are positively correlated whereas variables that are in the opposite direction are negatively correlated (Esbensen, 2004). This apparently provides the same message as the correlation analysis, but not only restricted to pairwise comparisons. Since variable $\mathrm{CH}_{4}$ and total gas production were in a close direction in the loading plot of PCA, it may imply that there is little probability in obtaining many tannincontaining plants with both desired characteristics, i.e. low $\mathrm{CH}_{4}$ production potential and high forage quality. Therefore, the screening results of this approach were largely in agreement with the univariate approach. This is probably connected to the role of tannins in mitigating $\mathrm{CH}_{4}$ emission as discussed above but reducing the forage quality as well at the same time. The adverse effects of tannins on forage digestibility have been well-documented (Makkar, 2003b; Mueller-Harvey, 2006). However, this does not exclude the possibility of finding plants with both desired characteristics, like $R$. typhina (G2) in the present dataset, since the structure and the activity of tannins in each plants are quite diverse (Mueller-Harvey, 2006).

\section{CONCLUSION}

Plant phenolic contents may be used as an indicator for $\mathrm{CH}_{4}$ mitigating properties of the plants, although they are also reversely related to the forage quality. Different approaches, i.e. univariate, bivariate and multivariate (PCA) for screening of tannin-containing plants in relation to their ruminal $\mathrm{CH}_{4}$ emission in vitro led to similar results to certain extent. However, screening based on univariate approach has to be conducted cautiously since it does not consider the forage quality, which is also quite an important factor. The bivariate and multivariate approaches may overcome such problem by considering the forage quality related variable. Although almost all tannin-containing plants that possessed low $\mathrm{CH}_{4}$ emission had low quality in the present study, still, a good quality plant could be obtained, i.e. $R$. typhina. This is possible since great variation have occurred in the structure and activity of each plant phenolics. The searching of plants with both desired characteristics is subjected to further research.

\section{REFERENCES}

AOAC. 1997. Official Methods of Analysis. Association of Official Analytical Chemists, Arlington, USA.

Beauchemin, K.A., M. Kreuzer, F. O'Mara and T.A.McAllister. 2008. Nutritional management for enteric methane abatement: a review. Aust. J. Exp. Agric. 48: 21-27.

Bhatta, R., Y. Uyeno, K. Tajima, A. Takenaka, Y. Yabumoto, I. Nonaka, O. Enishi and M. Kurihara. 2009. Difference in the nature of tannins on in vitro ruminal methane and volatile fatty acid production and on methanogenic archaea and protozoal populations. J. Dairy Sci. 92: 5512-5522.

Bodas, R., S. Lopez, M. Fernandez, R. GarciaGonzalez, A.B. Rodriguez, R.J. Wallace and J.S. Gonzalez. 2008. In vitro screening of the potential of numerous plant species as antimethanogenic feed additives for ruminants. Anim. Feed Sci. Technol. 145: 245-258.

Esbensen, K.H. 2004. Multivariate Data Analysis - In Practice. $5^{\text {th }}$ Edition. CAMO Software AS, Oslo, Norway.

Garcia-Gonzalez, R., S. Lopez, M. Fernandez, R. Bodas and J.S. Gonzalez. 2008. Screening the activity of plants and spices for decreasing ruminal methane production in vitro. Anim. Feed Sci. Technol. 147: 36-52. 
Goel, G., H.P.S. Makkar and K. Becker. 2008. Effect of Sesbania sesban and Carduus pycnocephalus and Fenugreek (Trigonella foenum-graecum L.) seeds and their extracts on partitioning of nutrients from roughageand concentrate-based feeds to methane. Anim. Feed Sci. Technol. 147: 72-89.

Jayanegara, A., N. Togtokhbayar, H.P.S. Makkar and K. Becker. 2009a. Tannins determined by various methods as predictors of methane production reduction potential of plants by an in vitro rumen fermentation system. Anim. Feed Sci. Technol. 150: 230-237.

Jayanegara, A., H.P.S. Makkar and K. Becker. 2009b. Methane reduction effect of simple phenolic acids evaluated by in vitro Hohenheim gas production method. Proc. Soc. Nutr. Physiol. 18:98.

Jayanegara, A., E. Wina, C.R. Soliva, S. Marquardt, M. Kreuzer and F. Leiber. 2011a. Dependence of forage quality and methanogenic potential of tropical plants on their phenolic fractions as determined by principal component analysis. Anim. Feed Sci. Technol. 163: 231-243.

Jayanegara, A., S. Marquardt, M. Kreuzer and F. Leiber. 2011b. Nutrient and energy content, in vitro ruminal fermentation characteristics and methanogenic potential of alpine forage plant species during early summer. J. Sci. Food Agric. 91: 1863-1870.

Makkar, H.P.S. 2003a. Quantification of Tannins in Tree and Shrub Foliage: A Laboratory Manual. Kluwer Academic Publishers, Dordrecht, The Netherlands.

Makkar, H.P.S. 2003b. Effects and fate of tannins in ruminant animals, adaptation to tannins, and strategies to overcome detrimental effects of feeding tannin-rich feeds. Small Rum. Res. 49: 241-256.

McCrabb, G.J. and R.A. Hunter. 1999. Prediction of methane emissions from beef cattle in tropical production systems. Aust. J. Agric. Res. 50: 1335-1340.

McSweeney, C.S., B. Palmer, D.M. McNeill and D.O. Krause. 2001. Microbial interactions with tannins: nutritional consequences for ruminants. Anim. Feed Sci. Technol. 91:8393.

Menke, K.H. and H. Steingass. 1988. Estimation of the energetic feed value obtained from chemical analysis and in vitro gas production using rumen fluid. Anim. Res. Dev. 28: 7-55.

Moss, A.R., J.P. Jouany and J. Newbold. 2000.
Methane production by ruminants: its contribution to global warming. Ann. Zootech. 49: 231-253.

Mueller-Harvey, I. 2006. Unravelling the conundrum of tannins in animal nutrition and health. J. Sci. Food Agric. 86:20102037.

SigmaPlot. 2008. SigmaPlot Software version 11.0. Systat Software Inc., San Jose, USA.

Singh, B., A. Sahoo, R. Sharma and T.K. Bhat. 2005. Effect of polyethylene glycol on gas production parameters and nitrogen disappearance of some tree forages. Anim. Feed Sci. Technol. 123-124: 351-364.

Soliva, C.R. and H.D. Hess. 2007. Measuring methane emission of ruminants by in vitro and in vivo techniques. In: Makkar, H.P.S. and P.E. Vercoe (Eds.). Measuring Methane Production from Ruminants. Springer, Dordrecht, The Netherlands.

Soliva, C.R., A.B. Zeleke, C. Clement, H.D. Hess, V. Fievez and M. Kreuzer. 2008. In vitro screening of various tropical foliages, seeds, fruits and medicinal plants for low methane and high ammonia generating potentials in the rumen. Anim. Feed Sci. Technol. 147: 53-71.

SPSS Inc. 2008. SPSS Statistics version 17.0. SPSS Inc., Chicago, USA.

Tavendale, M.H., L.P. Meagher, D. Pacheco, N. Walker, G.T. Attwood and S. Sivakumaran. 2005. Methane production from in vitro rumen incubations with Lotus pedunculatus and Medicago sativa, and effects of extractable condensed tannin fractions on methanogenesis. Anim. Feed Sci. Technol. 123-124: 403-419.

Tiemann, T.T., C.E. Lascano, H.R. Wettstein, A.C. Mayer, M. Kreuzer and H.D. Hess. 2008. Effect of the tropical tannin-rich shrub legumes Calliandra calothyrsus and Flemingia macrophylla on methane emission and nitrogen and energy balance in growing lambs. Animal 2: 790-799.

Van Soest, P.J., J.B. Robertson and B.A. Lewis. 1991. Methods for dietary fiber, neutral detergent fiber, and nonstarch polysaccharides in relation to animal nutrition. J. Dairy Sci. 74: 3583-3597.

Vogels, G.D., W.F. Hoppe and C.K. Stumm. 1980. Association of methanogenic bacteria with rumen ciliates. Appl. Environ. Microbiol. 40: 608-612. 